\title{
Soil-landform-plant-community relationships of a periglacial landscape on Potter Peninsula, maritime Antarctica
}

\author{
E. L. Poelking ${ }^{1}$, C. E. R. Schaefer ${ }^{2}$, E. I. Fernandes Filho ${ }^{2}$, A. M. de Andrade ${ }^{3}$, and A. A. Spielmann ${ }^{4}$ \\ ${ }^{1}$ Centro de Ciências Agrárias Ambientais e Biológicas, Universidade Federal do Recôncavo da Bahia, Brazil \\ ${ }^{2}$ Departamento de Solos, Universidade Federal de Viçosa, Brazil \\ ${ }^{3}$ Departamento de Geografia, Universidade Federal do Rio Grande do Sul, Brazil \\ ${ }^{4}$ Centro de Ciências Biológicas e da Saúde, Universidade Federal do Mato Grosso do Sul, Brazil \\ Correspondence to: E. L. Poelking (everton@ufrb.edu.br)
}

Received: 30 March 2014 - Published in Solid Earth Discuss.: 6 August 2014

Revised: 26 October 2014 - Accepted: 27 October 2014 - Published: 27 May 2015

\begin{abstract}
Integrated studies on the interplay between soils, periglacial geomorphology and plant communities are crucial for the understanding of climate change effects on terrestrial ecosystems of maritime Antarctica, one of the most sensitive areas to global warming. Knowledge on physical environmental factors that influence plant communities can greatly benefit studies on the monitoring of climate change in maritime Antarctica, where new ice-free areas are being constantly exposed, allowing plant growth and organic carbon inputs. The relationship between topography, plant communities and soils was investigated on Potter Peninsula, King George Island, maritime Antarctica. We mapped the occurrence and distribution of plant communities and identified soil-landform-vegetation relationships. The vegetation map was obtained by classification of a QuickBird image, coupled with detailed landform and characterization of 18 soil profiles. The sub-formations were identified and classified, and we also determined the total elemental composition of lichens, mosses and grasses. Plant communities on Potter Peninsula occupy $23 \%$ of the ice-free area, at different landscape positions, showing decreasing diversity and biomass from the coastal zone to inland areas where sub-desert conditions prevail. There is a clear dependency between landform and vegetated soils. Soils that have greater moisture or are poorly drained, and with acid to neutral $\mathrm{pH}$, are favourable for moss sub-formations. Saline, organic-matterrich ornithogenic soils of former penguin rookeries have greater biomass and diversity, with mixed associations of mosses and grasses, while stable felsenmeers and flat rocky cryoplanation surfaces are the preferred sites for Usnea and
\end{abstract}

Himantormia lugubris lichens at the highest surface. Lichens sub-formations cover the largest vegetated area, showing varying associations with mosses.

\section{Introduction}

Ice-free areas in maritime Antarctica have a peculiar flora dominated by a "fellfield" physiognomy, cryptogams with dominance of bryophytes (including mosses and liverworts), two species of talus algae (Prasiola crispa and Prasiola cladophylla) and approximately 360 known species of lichens. Only two native phanerogams occur (Antarctic hair grass, Deschampsia antarctica Desv., and Antarctic pearlwort, Colonbanthus quitensis (Kunth) Bartl.; Øvstedal and Smith, 2001).

The poorly diverse maritime Antarctic tundra ecosystems are best developed on ice-free areas under strong faunal influence during the summer period. The most important sites are coastal penguin rookeries, which provide suitable conditions for plant diversity in their marginal areas (Allen et al., 1967; Tatur and Myrcha, 1989; Tatur et al., 1997; Michel et al., 2006; Smykla et al., 2007; Simas et al., 2007; Victoria et al., 2013). As one moves inland, the vegetation becomes progressively sparse and less structured. Most biotic communities occur as small isolated patches, adapted to cold climate, relatively low light, high UV radiation and winter snow coverage (Bargagli et al., 1995).

Abandoned rookeries are characterized by dense vegetation in nitrogen- and phosphate-rich ornithogenic soils, 


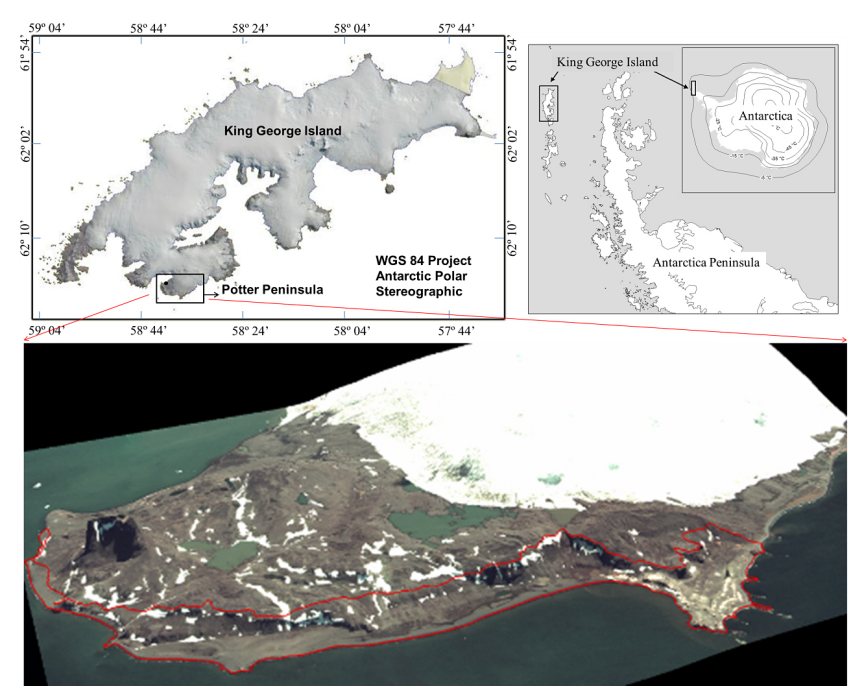

Figure 1. Top left: localization map of Potter Peninsula in the maritime Antarctica. Top right: location in relation to Antarctic Peninsula. Bottom: Quickbird 2 image in perspective view. The red line shows the limit of ASPA 132.

which maintain high levels of available nutrients centuries or millenniums after abandonment (Myrcha and Tatur, 1991). The South Shetland Islands uplift of $18-20 \mathrm{~m}$ above sea level during the Holocene period as a consequence of the glaciostatic movement following glacial retreat (Fretwell et al., 2010). During the last 500 years the environment are progressively stabling and occupied by plants (Birkenmajer, 1998). Throughout this period, the penguin rookery of Stranger Point progressively moved down from the highest cliff to the recent beaches (Tatur and Myrcha, 1989).

Ornithogenic soils are the most important compartment of immobilized carbon (C) in Antarctic ice-free areas. The presence of two flowering plants $-D$. antarctica and $C$. quitensis - contributes to higher organic $\mathrm{C}$ levels, and is positively related to soil depth (Simas et al., 2007). Organic matter in such soils is richer in nitrogen $(\mathrm{N})$ and easily thermodegradable compounds, representing a considerable pool of easily degradable $\mathrm{C}$ in the maritime Antarctic environment (Michel et al., 2006). Consequently, these soils may be vulnerable to $\mathrm{C}$ losses to the atmosphere in response to global warming and permafrost degradation (Michel et al., 2006; Simas et al., 2007).

At Stranger Point, in the eastern part of Potter Peninsula, Tatur et al. (1997) observed that high nutrient status appears to determine the vegetation distribution and zonation in both active and abandoned rookeries. $D$. antarctica is relatively abundant in ornithogenic soils of abandoned rookeries and in marginal areas of active rookeries. Schaefer, C. E. G. R. et al. (2004) and Francelino et al. (2011) found colonies of $D$. antarctica and $C$. quitensis in stable and shallow soils at nearby Keller Peninsula, close to bird nests. Large vegetated uplands and slopes are occupied by Usnea sp. lichen mainly in well-drained moraines, felsenmeer and rocky slopes (Francelino et al., 2011). Mosses are locally extensive in hydromorphic, waterlogged soils. Plant succession begins with talus algae and cyanobacteria mats, and culminates with a mixed formation of lichens, bryophytes and eventually higher plants. Vegetation development is particularly sensitive to the nutrient transfer from marine to terrestrial ecosystems by faunal action (Schaefer, C. N. et al., 2004). Hence, vegetation can serve as a proxy of environmental changes and human-mediated pollution (Bargagli et al., 1995; Poblet et al., 1997).

The assessment of plant communities' temporal dynamics and ecological relationships with physical attributes, such as soil parent material, slope, and climate (Schaefer, C. E. G. R. et al., 2004), are key issues for Antarctic ecology. Understanding the factors affecting the distribution of vegetation in Antarctica ice-free areas can help in studying climate and landscape change at greater scales. To detect changes in community structure and extent, there is a need for improved instrumental monitoring of the physicochemical and biological characteristics of periglacial areas in order to understand and model the effects of global change on water, permafrost, soil and primary ecosystem processes (Bargagli, 2005). Longton (1988), based on many previous works, adapted a vegetation classification system to maritime Antarctica, where the grouping of different species was based on growing forms and habitats. The criteria for separating formations were based on habitats and growth forms of the most abundant species. The tundra sub-formation units are based on growth form, and the predominant association refers to the floristic similarity between the components (Smith and Gimingham, 1976).

Systematic vegetation mapping at large scale in Antarctica is very limited. At regional scales and low resolution, the application of NOAA AVHRR for vegetation analysis in Antarctica has failed to detect the highly fragmented and dispersed nature of local vegetation (Fretwell et al., 2011). At greater scales, most previous studies have focused on field floristic surveys aided by GPS (Kim et al., 2007; Schaefer, C. E. G. R. et al., 2004; Victoria et al., 2013), and the identification of aerial photograph mosaics (Francelino et al., 2011) resulting in vegetation maps of large scales in small ice-free areas, or large areas with remote sensing images at low resolution (Fretwell et al., 2011). On the other hand, in isolated areas with heterogeneous distribution of vegetation in maritime Antarctica, traditional vegetation mapping is more difficult at large scales. In this regard, high-resolution satellite images are excellent alternatives. Satellite images obtained through remote sensing can help the monitoring of climate change impacts on ice-free areas with greater efficiency and higher resolution. A baseline survey of the amount and distribution of vegetation is required for comparison against in order to monitor future changes (Fretwell et al., 2011).

It is widely recognized that the relationship between Antarctic vegetation and abiotic factors, such as soils and 
Table 1. Vegetation community classification of Potter Peninsula (adapted from Longton, 1988).

\begin{tabular}{|c|c|c|c|}
\hline Vegetation communities & Landforms and soils & Dominant plant species & Sociation plants \\
\hline $\begin{array}{l}\text { Tall moss turf and carpet } \\
\text { sub-formation }\end{array}$ & $\begin{array}{l}\text { Mosses in wet, hydromorphic areas (partially associated } \\
\text { with cyanobacteria mats) in wet marine terrace soils } \\
\text { (with < } 10 \% \text { slope) (P5) (P14). At Stranger Point, very } \\
\text { dense moss carpets occur in old stable talus (P14) }(30 \% \\
\text { slope). }\end{array}$ & $\begin{array}{l}\text { Sanionia uncinata, Andreaea, } \\
\text { Phormidium sp., Polytrichum, } \\
\text { Bryum }\end{array}$ & $\begin{array}{l}\text { Cyanobacteria; D. antarctica; } \\
\text { without lichens, Fig. } 5 \mathrm{a}\end{array}$ \\
\hline $\begin{array}{l}\text { Moss turf and grass } \\
\text { sub-formation }\end{array}$ & $\begin{array}{l}\text { Mosses and } D \text {. antarctica on well-drained marine ter- } \\
\text { races and ornithogenic soils of abandoned rookeries and } \\
\text { petrel nests }(\mathrm{P} 11, \mathrm{P} 13, \mathrm{P} 17, \mathrm{P} 18) \text {. }\end{array}$ & $\begin{array}{l}\text { Sanionia } \text { sp., D. antarctica, } \\
\text { Polytrichum }\end{array}$ & $\begin{array}{l}\text { Umbilicaria; Cladonia sp., } \\
\text { Himmantormia } \text { sp.; } \\
\text { Neurophogum sp., Fig. } 5 \mathrm{~b}\end{array}$ \\
\hline $\begin{array}{l}\text { Fruticulose and foliose lichen } \\
\text { sub-formation }\end{array}$ & $\begin{array}{l}\text { Homogeneous lichen fields in well-drained rocky, } \\
\text { skeletal soils (P1, P2, P3, P7) of stables cryoplanation } \\
\text { surfaces. }\end{array}$ & $\begin{array}{l}\text { Usnea sp., Ochrolechia } \text { cf. } \\
\text { frigida, Cladonia } \text { sp., } \\
\text { Neurophogum, Himantormia }\end{array}$ & $\begin{array}{l}\text { Polytrichum, Bryum, Sanionia } \\
\text {, Fig. } 5 \mathrm{c}\end{array}$ \\
\hline $\begin{array}{l}\text { Fruticulose lichens/short } \\
\text { moss turf and cushion } \\
\text { sub-formation }\end{array}$ & $\begin{array}{l}\text { Mosses and foliose/crustose lichen communities in or- } \\
\text { nithogenic soils on marine terraces (P13, P6) and } \\
\text { weakly ornithogenic soils (P4, P10, P15). Occurrence } \\
\text { on dry to moist habitats, acid and cryoturbic soils de- } \\
\text { rived from moraines and uplifted marine terraces. }\end{array}$ & $\begin{array}{l}\text { Polytrichum sp., Usnea sp., } \\
\text { Sanionia uncinata, }\end{array}$ & $\begin{array}{l}\text { D. antarctica; Sanionia sp.; } \\
\text { Prasiola; Polytrichales, Fig. } 5 \mathrm{~d}\end{array}$ \\
\hline $\begin{array}{l}\text { Macroscopic alga } \\
\text { sub-formation }\end{array}$ & $\begin{array}{l}\text { Prasiola crispa in the vicinity of penguin and giant pe- } \\
\text { trel rookeries (recent guano). Habitats with high ammo- } \\
\text { nia in Stranger Point occur in widespread marine ter- } \\
\text { races (flat slopes }<5 \% \text { ). }\end{array}$ & P. crispa, & $\begin{array}{l}\text { Cyanobacteria. D, antarctica; } \\
\text { Umbilicaria and Ramalina sp. } \\
\text {, Fig. 5e }\end{array}$ \\
\hline
\end{tabular}

Table 2. Spectral characteristics of QuickBird satellite image.

\begin{tabular}{lrr}
\hline Spectral band & Wavelength $(\mathrm{nm})$ & Spatial resolution $(\mathrm{m})$ \\
\hline Panchromatic & 405 to 1053 & 0.60 \\
Blue & 430 to 545 & \\
Green & 466 to 620 & \\
Red & 590 to 710 & 2.44 \\
NIR & 715 to 918 & \\
\hline
\end{tabular}

landforms, is relevant for the understanding of the ecological evolution of Antarctic landscapes (Francelino et al., 2011) and how they respond to environmental changes. Environmental monitoring including remote sensing and in situ measurements, mapping the extent of vegetation, and biological characterization at community and population levels (both floristically and faunistically) can help to detect changes in community structure and extent (Bargagli, 2005). The present work aims to map the vegetation communities with high-resolution satellite images and investigated the relationships between vegetation communities in ice-free areas on Potter Peninsula and selected geomorphological and pedological features. In addition, we evaluated some basic plant chemical composition to compare with the amounts of available nutrients in soils.

\section{Study area}

Potter Peninsula is located on King George Island (Fig. 1), part of the South Shetland archipelago, maritime Antarctica, at the following coordinates: $62^{\circ} 13.5^{\prime}-62^{\circ} 16^{\prime} \mathrm{S}, 58^{\circ} 42^{\prime}-$ $58^{\circ} 33^{\prime} \mathrm{W}$. Potter Peninsula stretches over a $6 \mathrm{~km}$ long east- west extension, and $3.5 \mathrm{~km}$ long north-south axis, with a total of approximately $7.13 \mathrm{~km}^{2}$ ice-free area during the summer (Fig. 1). The Köppen climate classification for King George Island is ET. Average annual air temperature is $-2.8^{\circ} \mathrm{C}$, with summer temperature ranging from -1.3 to $2.7^{\circ} \mathrm{C}$ and winter from -15.5 to $-1.0^{\circ} \mathrm{C}$ (Ferron et al., 2004). In terms of geology, Potter Peninsula belongs to the Warszawa tectonic block, which is dominated by a volcanic rock sequence formed between 50.6 and 49.1 Ma (Kraus and del Valle, 2008). The geology mainly comprises basalt and basaltic andesite, frontal and basal moraines, and different levels of marine terraces. The peninsula has been shaped by glacial action, moraines formed with typical rock outcrops, and different levels of terraces (Birkenmajer, 1998; Kraus and del Valle, 2008). More details can be found in Birkenmajer (1998). The soils of Potter Peninsula are typical for a periglacial environment, with poorly developed soils, coarse sand and gravel, sandy texture, and ornithogenic soils in marine beaches; permafrost was found at about 90 to $100 \mathrm{~cm}$ depth (Poelking, 2011).

Potter Peninsula encompasses Antarctic Specially Protected Area no. 132 (ASPA 132) along the coastal area, where concentration of Antarctica fauna is greater, including penguin rookeries (Pygocelis sp.) and populations of marine mammals, such as Weddell seals (Leptonychotes weddellii), elephant seals (Mirounga leonina) and fur seals (Arctocephalus gazella). In the elevated areas, skuas (Catharacta sp.) and giant petrel (Macronectes giganteus) nests are concentrated. This fauna accounts for sea-land nutrient transfer, fertilizing soil environments through accumulation of guano excreta and dead remains. 

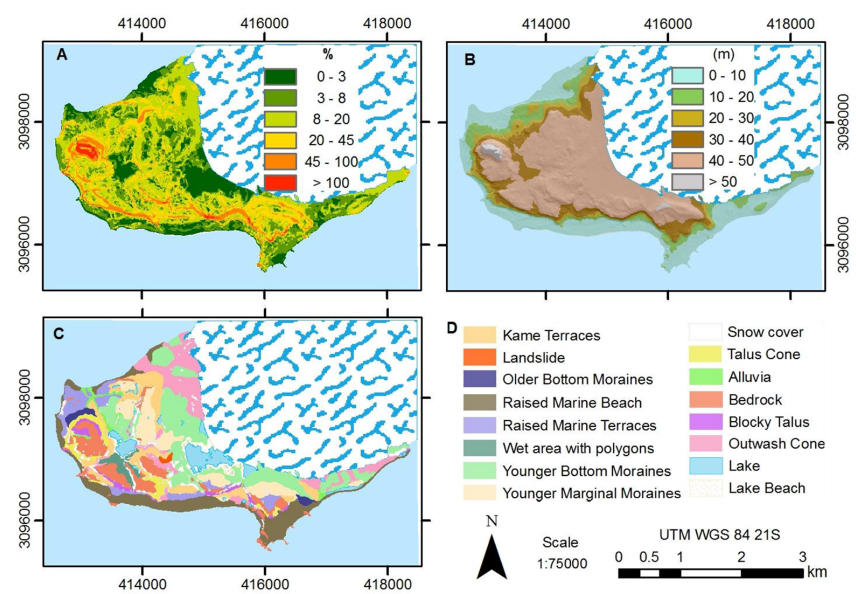

Figure 2. Map of hypsometry (a), altimetry (b) and geomorphology (Birkenmajer, 1988) (c). Legend is shown in (d) (Poelking, 2011).

\section{Material and methods}

\subsection{Vegetation community classification}

Plant samples were collected and identified during fieldwork in 2008 at each soil sampling point. The vegetation community classification was adapted from Longton (1988) based on local variations and main dominant species. Thematic classes and descriptions are presented in Table 1.

\subsection{Vegetation mapping}

For vegetation mapping we used a QuickBird image (January 2007) with four separate multispectral bands and a spatial resolution of $2.4 \mathrm{~m}$. We used the NDVI (normalized difference vegetation index) to help in the discrimination of vegetation class following Eq. 1:

$\mathrm{NDVI}=\frac{(\mathrm{NIR}-R)}{(\mathrm{NIR}+R)}$

where NIR is the near-infrared band and $R$ is the red band.

The image was georeferenced and orthorectified using control points obtained in the field with a Leica DGPS and coupled with a digital elevation model (Lusky et al., 2001) following ArcGIS 9.3 routine procedures. For the supervised image classification, we adopted the Maxver classifier (maximum-likelihood estimation) using Idrisi Andes software, in which the training samples were demarcated based on field observations and intensive plant collection in the summer of 2008 using precise DGPS location. The classification check was done through revisits on field, with checkpoints taken by GPS. The kappa index was adopted to verify the classified accuracy for different vegetation cover classes (Cogalton and Green, 1999). The kappa coefficient $(K)$ is a measure of the real agreement minus the agreement by chance; in other words, it is a measure of how much the classification is in agreement with the reference data calculated

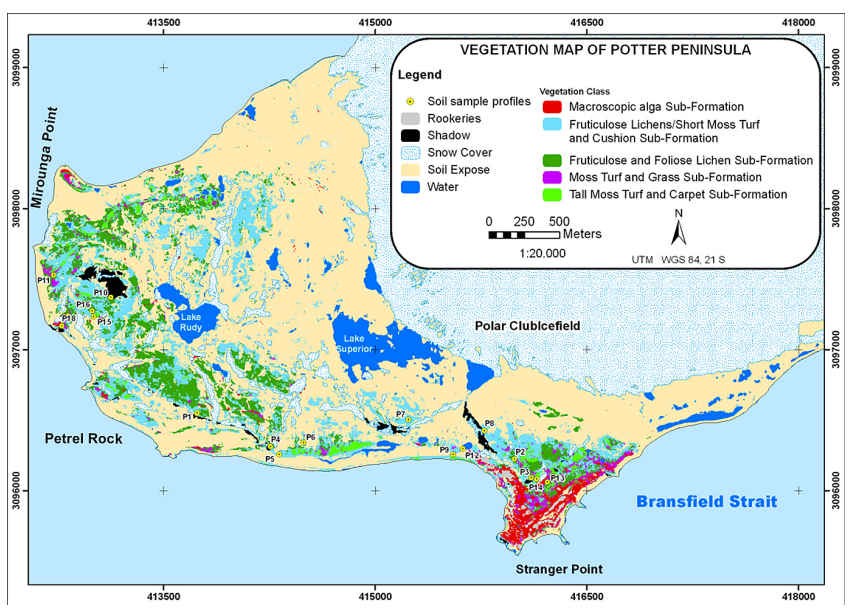

Figure 3. Vegetation map of Potter Peninsula, maritime Antarctica.

using Eq. 2:

$\hat{k}=\frac{N \sum_{i=1}^{r} x_{i i}-\sum_{i=1}^{r}\left(x_{i+} \cdot x_{+i}\right)}{N^{2}-\sum_{i=1}^{r}\left(x_{i+} \cdot x_{+i}\right)}$,

where $K$ is the kappa coefficient estimate; $x_{i}$ is the value in row $i$ and column $i, x_{i} i$ is the value in row $i$ and column $i, x_{i}+$ is the sum of row $i, x_{+} i$ is the sum of column $i$ of the confusion matrix, $N$ is the total number of samples, and $r$ is the total number of classes. According to Cogalton and Green (1999), values above 0.8 are considered excellent.

\subsection{Soil sampling, analytical procedures and plant chemical analysis}

In total, 18 soil pits were described. Soil classification followed the World Reference Base for Soil Resources (WRB) classification system (IUSS Working Group WRB, 2006). Soil samples were collected, air-dried, passed through a $2 \mathrm{~mm}$ sieve, and submitted to chemical and physical analyses. Soil $\mathrm{pH}$, exchangeable nutrients and texture were determined according to Embrapa (1997).

Collected plant samples were washed to remove soil, dried at $70^{\circ} \mathrm{C}$ for $72 \mathrm{~h}$ and milled into particles smaller than $0.5 \mathrm{~mm}$. Phosphorus $(\mathrm{P})$, potassium $(\mathrm{K})$, calcium $(\mathrm{Ca})$, magnesium $(\mathrm{Mg})$, zinc $(\mathrm{Zn})$, copper $(\mathrm{Cu})$, manganese $(\mathrm{Mn})$ and iron $(\mathrm{Fe})$ were measured by means of nitropercloric digestion of $0.5 \mathrm{~g}$ of sample in $10 \mathrm{~mL}$ of $\mathrm{HNO} 3$ at $200{ }^{\circ} \mathrm{C}$. P was determined using a colorimetric assay, assessing the phosphomolybdate reduction with vitamin C (Braga and Deffelipo, 1974). Potassium was measured via flame emission photometry, and $\mathrm{Ca}, \mathrm{Mg}, \mathrm{Fe}, \mathrm{Zn}, \mathrm{Cu}$ and $\mathrm{Mn}$ via atomic absorption spectrophotometry (Tedesco et al., 1995). 


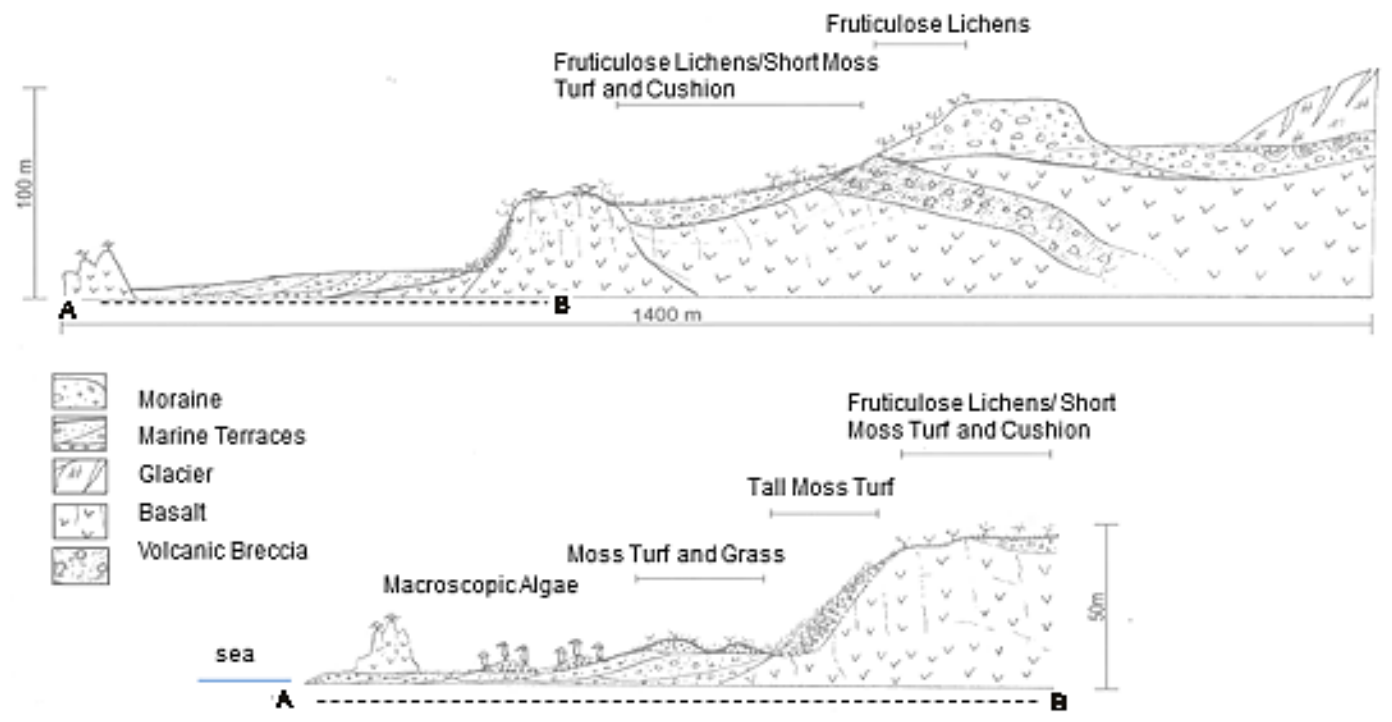

Figure 4. Topographic sequence and distribution of vegetation at Stranger Point, Potter Peninsula.

Table 3. Plant community classes and their relative areas on Potter Peninsula.

\begin{tabular}{lrr}
\hline Thematic class & \multicolumn{2}{c}{ Areas } \\
& (ha) & $\%$ \\
\hline Tall moss turf and carpet sub-formation & 9.46 & 1.31 \\
Moss turf and grass sub-formation & 9.23 & 1.28 \\
Fruticulose and foliose lichen sub-formation & 52.11 & 7.24 \\
Fruticulose lichens/short moss turf & 81.26 & 11.29 \\
and cushion sub-formation & & \\
Macroscopic alga sub-formation & 12.17 & 1.69 \\
Rookeries & 4.4 & 0.61 \\
Bare soil & 461.57 & 64.11 \\
Water bodies & 43.94 & 6.1 \\
Snow cover & 39.05 & 5.42 \\
Shadow & 6.77 & 0.94 \\
Total & 719.96 & 100 \\
\hline
\end{tabular}

\section{Results}

\subsection{Vegetation mapping}

The infrared wave band $(0.76$ to $0.90 \mathrm{~mm})$ allowed for distinguishing between vegetated areas under different photosynthetic activities compared with other types of surfaces (e.g. snow, exposed soil, water bodies). The NDVI offers a clear distinction between the surfaces according to different spectral responses of the infrared and red bands (Fretwell et al., 2011).

Figure 3 shows a supervised classification map which produced a very satisfactory kappa index (0.90) according to Cogalton and Green (1999). Although we used a high-resolution image, a reliable automated classification of the vegetation was constrained by local microhabitats and the high heterogeneity of Antarctic plant communities, whose composition and distribution are controlled by the interaction of a wide range of factors and processes.

On Potter Peninsula, about $23 \%$ of ice-free areas are vegetated (Table 2) and widely distributed across the landscape. The most rich and diverse flora is found in the oldest exposed areas that developed after the Holocene deglaciation, as well as in ornithogenic landscapes. Recently exposed grounds, such as stable moraines, are being progressively occupied by patches of lichen and moss communities.

\subsection{Classification of plant communities}

Lichens showed the greatest diversity in most landscapes. They occurred in mixed forms associated with mosses and grasses in specific habitats. Extensive fields dominated by Usnea sp. and Himantormia lugubris occupy upland areas of stony soils or rock outcrops. Lichen and moss sub-formations are distributed in soils under little ornithogenic influence.

D. antarctica is widespread in well-drained ornithogenic soils, especially near penguin $(\mathrm{P} 12, \mathrm{P} 13)$ or giant petrel rookeries and associated pedoenvironments (P15, P 16, P17 and P18). Mat patches of the algae Prasiola were found on stable, homogeneous areas around bird nests, which contained high concentrations of ammonia. (P12 and 16). These patches form limited $\mathrm{N}$-rich habitats close to active rookeries on marine terraces at Stranger Point (Fig. 3).

Longton (1988) adapted a subjective hierarchical classification where major units were defined by the growth form of the community dominant species, while minor units reflected the floristic composition. The associations are characterized by codominant species or by restricted occurrence in more 
Table 4. Exchangeable nutrient concentration at surface horizons $(0-10 \mathrm{~cm})$ for the studied soils.

\begin{tabular}{lrrrrrrrrrrr}
\hline Profile & $\mathrm{N}$ & $\mathrm{P}$ & $\mathrm{K}$ & $\mathrm{Ca}$ & $\mathrm{Mg}$ & $\mathrm{Fe}$ & $\mathrm{Zn}$ & $\mathrm{Mn}$ & $\mathrm{Cu}$ & $\mathrm{pH}$ & $>2 \mathrm{~mm}$ \\
\hline & \multicolumn{1}{c}{$\mathrm{dag} \mathrm{kg}^{-1}$} & & \multicolumn{2}{c}{$\mathrm{mg} \mathrm{dm}^{-3}$} & & & & $\mathrm{H}_{2} \mathrm{O}$ & $\%$ \\
\hline P1 & 0.31 & 66.1 & 95 & 496 & 264 & 58.89 & 0.58 & 6.77 & 2.32 & 5.58 & 55 \\
P2 & 0.48 & 158.2 & 187 & 988 & 724.8 & 548.84 & 5 & 13.3 & 10.87 & 5.19 & 44 \\
P3 & 1.09 & 443.1 & 298 & 384 & 307.2 & 171.4 & 1.17 & 24.27 & 5.28 & 4.51 & 93 \\
P4 & 0.48 & 554.8 & 154 & 246 & 196.8 & 399.01 & 0.82 & 2.77 & 6.07 & 4.99 & 42 \\
P5 & 0.04 & 150.9 & 111 & 2240 & 1026 & 114.11 & 0.71 & 38.18 & 7.08 & 6.13 & 64 \\
P6 & 0.72 & 419.2 & 125 & 220 & 102 & 280.46 & 1.99 & 3.79 & 7.19 & 4.33 & 80 \\
P7 & 0.42 & 68.5 & 117 & 510 & 373.2 & 256.22 & 5.32 & 18.93 & 11.78 & 5.67 & 74 \\
P8 & 0.17 & 705 & 157 & 876 & 619.2 & 176.58 & 0.91 & 21.67 & 10.27 & 5.98 & 52 \\
P10 & 0.37 & 44.3 & 161 & 1614 & 526.8 & 135.95 & 0.81 & 82.31 & 7.21 & 6.26 & 49 \\
P11 & 0.08 & 127.7 & 124 & 1716 & 385.2 & 88.71 & 0.64 & 14.27 & 6.17 & 6.14 & 46 \\
P12 & 0.14 & 218.5 & 232 & 2384 & 446.4 & 67.5 & 0.95 & 36.80 & 7.37 & 5.06 & 41 \\
P13 & 0.44 & 757 & 213 & 268 & 64.8 & 546.2 & 3.6 & 6.4 & 14.9 & 4.7 & 66 \\
P14 & 0.56 & 829.1 & 193 & 516 & 106.8 & 421.5 & 7.35 & 16.82 & 17.65 & 4.42 & 81 \\
P15 & 1.29 & 62.4 & 103 & 458 & 260.4 & 292.79 & 1.59 & 6.05 & 3.65 & 5.01 & 59 \\
P16 & 0.76 & 617.8 & 248 & 436 & 214.8 & 357.4 & 4.48 & 3.9 & 2.14 & 4.52 & 91 \\
P17 & 1.28 & 549 & 43 & 150 & 38.4 & 255.08 & 1.23 & 2.29 & 2.06 & 4.42 & 0 \\
P18 & 0.01 & 118.9 & 82 & 140 & 60 & 267.83 & 0.91 & 11.31 & 10.35 & 5.18 & 1 \\
\hline
\end{tabular}

P, K, Ca, Mg Fe, Zn, Mn and Cu: Melich 1 exchangeable; N: Kjendal method
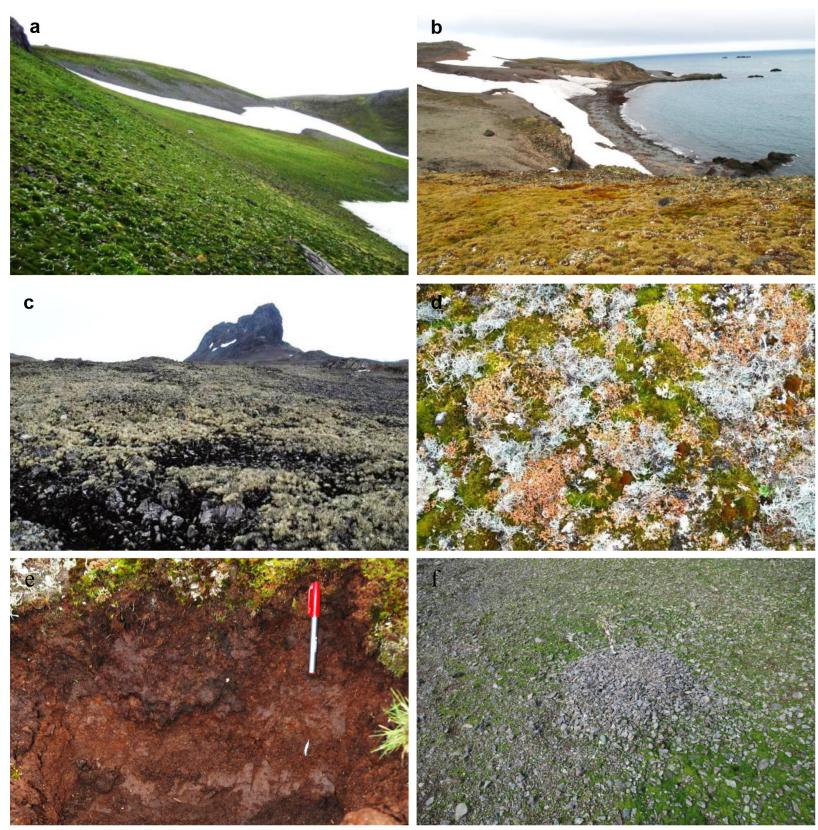

Figure 5. (a) Moss turf carpet on Stranger Point talus slope, covered with Sanionia and Polytrichales. (b) D. antarctica grass tuft around giant petrel nests in Petrel Rock. (c) Cryoplanation surface covered with fruticulose lichens Usnea sp. and Himantormia on skeletic soils. (d) Plant communities of mixed fruticulose lichens and Sanionia moss tufts in ornithogenic soils (P15). (e) P17 (Histic Leptic Cryosols (Ornithic, Arenic)) formed by humus cumulation around giant petrel nest. (f) Prasiola crispa mat around bird nest (P16). specifics habitats (Longton, 1988; Smith and Girmingham, 1976).

The proportion of ice-free ground surface on Potter Peninsula clearly reduces with increasing altitude and distance from the coastal zone, although upland areas are not lifeless. Recently exposed bare ground adjacent to Polar Club Glacier appears devoid of plants, apart from dense cyanobacteria mats growing in oligotrophic lakes and temporary shallow pools.

Old exposed grounds on Potter Peninsula have a wide variety of plant communities. Lower terrace levels are occupied by dense stands of mosses and $D$. antarctica replacing areas formerly occupied by pure moss stands, thus revealing an advanced stage of succession following uplift. Poorly drained areas close to pools and depressions rich in leachates coming from nearby penguin rookeries are associated with Prasiola and nitrophilous mosses. Upland, exposed shallow and rocky soils are covered with dense fields of Usnea sp. and $H$. lugubris. Recently exposed nearby soils showed a sparse development of $D$. antarctica tufts.

\subsubsection{Tall moss turf and carpet sub-formation}

Bryophytes are typically associated with moist, hydromorphic soils or humid slopes and wet microhabitats protected from strong winds. There, Polytrichales and Sanionia formed thick, uniform carpets (P14) (Fig. 4a) or cushions, establishing occasional limited associations with tufts of $D$. antarctica (P15) and cyanobacteria mats, the latter in permanently water-saturated soils of marine terraces (P5). Soils in these areas are relatively fertile due to high inputs 
Table 5. Range and mean values of macro- and micronutrients in lichens, mosses and D. antarctica of ice-free areas on Potter Peninsula.

\begin{tabular}{|c|c|c|c|c|c|c|c|c|c|}
\hline & $\mathrm{N}$ & $\mathrm{P}$ & $\mathrm{K}$ & $\mathrm{Ca}$ & $\mathrm{Mg}$ & $\mathrm{Fe}$ & $\mathrm{Zn}$ & $\mathrm{Mn}$ & $\mathrm{Cu}$ \\
\hline & \multicolumn{6}{|c|}{$\%$} & \multicolumn{3}{|c|}{$\mathrm{mg} \mathrm{kg}^{-1}$} \\
\hline & \multicolumn{9}{|c|}{ Lichens } \\
\hline Minimum & 0.59 & 0.04 & 0.09 & 0.05 & 0.04 & 0.11 & 6.4 & 13.5 & 0.1 \\
\hline Maximum & 1.5 & 0.22 & 0.26 & 0.86 & 0.32 & 1.86 & 40.1 & 277.7 & 90.1 \\
\hline Mean $n=7$ & 099 & 0.1 & 0.17 & 0.53 & 0.13 & 0.54 & 19.8 & 84 & 25.3 \\
\hline Standard deviation & 0.31 & 0.07 & 0.05 & 0.28 & 0.09 & 0.6 & 11.1 & 91.6 & 32.8 \\
\hline \multirow[t]{2}{*}{$\mathrm{CV} \%$} & 31 & 68.4 & 30.7 & 53.4 & 76.5 & 112.7 & 56.3 & 109.0 & 129.3 \\
\hline & \multicolumn{9}{|c|}{ Mosses } \\
\hline Minimum & 0.71 & 0.05 & 0.11 & 0.4 & 0.04 & 0.04 & 6.8 & 17.4 & 0.1 \\
\hline Maximum & 1.96 & 0.36 & 0.34 & 1.41 & 0.39 & 2.38 & 53.7 & 464.4 & 122.1 \\
\hline Mean $n=12$ & 1.22 & 0.17 & 0.19 & 0.85 & 0.26 & 1.26 & 33.9 & 209.7 & 37.6 \\
\hline Standard deviation & 0.41 & 0.09 & 0.06 & 0.32 & 0.11 & 0.8 & 14.8 & 119.6 & 33.3 \\
\hline \multirow[t]{2}{*}{$\mathrm{CV} \%$} & 33.8 & 56.3 & 33.9 & 37.0 & 42.1 & 63.2 & 43.7 & 57.0 & 88.7 \\
\hline & \multicolumn{9}{|c|}{ Grass } \\
\hline Minimum & 1.5 & 0.22 & 0.15 & 0.25 & 0.17 & 0.78 & 35.8 & 123.4 & 12.2 \\
\hline Maximum & 2.6 & 0.3 & 0.77 & 1.6 & 0.40 & 2.59 & 69.2 & 548.8 & 71.1 \\
\hline Mean $n=4$ & 1.87 & 0.27 & 0.37 & 0.79 & 0.28 & 1.64 & 49.3 & 277.3 & 44.2 \\
\hline Standard deviation & 0.52 & 0.03 & 0.29 & 0.58 & 0.09 & 0.79 & 14.1 & 197.1 & 29.8 \\
\hline $\mathrm{CV} \%$ & 28.1 & 13.2 & 77.0 & 73.4 & 34.2 & 48.2 & 28.7 & 71.1 & 67.4 \\
\hline
\end{tabular}

Table 6. Mean values of macro- and micronutrients reported in the literature for maritime Antarctica.

\begin{tabular}{|c|c|c|c|c|c|c|c|c|c|}
\hline Reference & $\mathrm{N}$ & $\mathrm{P}$ & $\mathrm{K}$ & $\mathrm{Ca}$ & $\mathrm{Mg}$ & $\mathrm{Fe}$ & $\mathrm{Zn}$ & $\mathrm{Mn}$ & $\mathrm{Cu}$ \\
\hline & & \multicolumn{5}{|c|}{$\%$} & \multicolumn{3}{|c|}{$\mathrm{mg} \mathrm{kg}^{-1}$} \\
\hline & \multicolumn{9}{|c|}{ Lichens } \\
\hline Admiralty Bay ${ }^{\mathrm{a}}$ & & 0.05 & 0.12 & 0.87 & 0.05 & 0.09 & 8.4 & 10.1 & 9.1 \\
\hline Admiralty Bay ${ }^{b}$ & & 0.07 & - & 1.41 & 0.22 & 1 & 23.9 & 138.8 & 19.3 \\
\hline \multirow[t]{2}{*}{ Potter Peninsula ${ }^{c}$} & & - & - & - & - & 0.07 & 10.3 & 30.2 & 4.5 \\
\hline & \multicolumn{9}{|c|}{ Mosses } \\
\hline Admiralty Bay ${ }^{\mathrm{a}}$ & & 0.22 & 0.33 & 0.75 & 0.57 & 1.58 & 43.7 & 301.4 & 58.1 \\
\hline Admiralty Bay ${ }^{b}$ & & 0.17 & - & 0.67 & 0.53 & 1.8 & 32.8 & 315.9 & 40.7 \\
\hline Potter Peninsula ${ }^{c}$ & & 0.68 & 0.61 & 0.39 & 0.3 & - & - & & \\
\hline \multirow[t]{2}{*}{ Signy ${ }^{d}$} & & 0.23 & 0.38 & 0.47 & 0.5 & & & & \\
\hline & \multicolumn{9}{|c|}{ Grass } \\
\hline Admiralty Bay ${ }^{\mathrm{a}}$ & & 0.21 & 0.32 & 0.52 & 0.43 & 0.8 & 42.8 & 265.9 & 45.6 \\
\hline Admiralty Bay ${ }^{b}$ & & 0.42 & - & 0.49 & 0.27 & 0.65 & 38.4 & 254 & 13.8 \\
\hline Signy & & 0.25 & 0.4 & 0.36 & 0.44 & - & - & - & - \\
\hline Stranger Point ${ }^{\mathrm{e}}$ & 2.5 & 0.4 & 1.5 & 0.2 & 0.2 & 0.05 & 30 & 60 & 10 \\
\hline
\end{tabular}

${ }^{\text {a }}$ Simas (2006), ${ }^{\mathrm{b}}$ Schaefer et al. (2004c), ${ }^{\mathrm{c}}$ Poblet et al. (1997), ${ }^{\mathrm{d}}$ Allen et al. (1967), ${ }^{\mathrm{e}}$ Tatur et al. (1997). 
Table 7. Correlation between soil macro- and micronutrients available and total plant amounts in the dry matter of mosses on Potter peninsula.

\begin{tabular}{lrrrrrrrrr}
\hline & $\mathrm{N}(m)$ & $\mathrm{P}(m)$ & $\mathrm{K}(m)$ & $\mathrm{Ca}(m)$ & $\mathrm{Mg}(m)$ & $\mathrm{Zn}(m)$ & $\mathrm{Fe}(m)$ & $\mathrm{Mn}(m)$ & $\mathrm{Cu}(m)$ \\
\hline $\mathrm{N}(s)$ & 0.34 & -0.06 & -0.49 & -0.06 & 0.06 & 0.09 & -0.22 & 0.05 & -0.17 \\
$\mathrm{P}(s)$ & 0.52 & $\mathbf{0 . 6 3}$ & 0.17 & 0.26 & 0.12 & 0.49 & -0.03 & -0.05 & 0.45 \\
$\mathrm{~K}(s)$ & -0.28 & 0.09 & 0.16 & 0.47 & 0.33 & 0.47 & 0.52 & 0.52 & 0.35 \\
$\mathrm{Ca}(s)$ & -0.28 & -0.19 & 0.09 & 0.25 & 0.28 & 0.06 & 0.31 & 0.39 & 0.11 \\
$\mathrm{Mg}(s)$ & -0.36 & -0.30 & 0.14 & 0.38 & 0.32 & 0.09 & 0.37 & 0.45 & 0.05 \\
$\mathrm{Zn}(s)$ & $\mathbf{0 . 6 4}$ & $\mathbf{0 . 7 0}$ & -0.04 & 0.04 & -0.05 & 0.44 & 0.10 & -0.11 & $\mathbf{0 . 7 3}$ \\
$\mathrm{Fe}(s)$ & 0.56 & $\mathbf{0 . 7 2}$ & 0.41 & 0.03 & 0.10 & 0.33 & 0.08 & -0.18 & 0.31 \\
$\mathrm{Mn}(s)$ & -0.24 & -0.24 & -0.24 & 0.04 & 0.13 & 0.06 & 0.29 & 0.48 & 0.19 \\
$\mathrm{Cu}(s)$ & 0.43 & $\mathbf{0 . 7 7}$ & 0.35 & 0.15 & 0.12 & 0.52 & 0.42 & 0.07 & $\mathbf{0 . 7 6}$ \\
\hline
\end{tabular}

Note: marked correlations are significant at $p<0.05 \mathrm{~N}=12 ;(m)$ : mosses; $(s)$ : soil

Table 8. Correlation between soil macro- and micronutrients availables and total plant amounts in D. antarctica growing on Potter Peninsula.

\begin{tabular}{lrrrrrrrrr}
\hline & $\mathrm{N}(g)$ & $\mathrm{P}(g)$ & $\mathrm{K}(g)$ & $\mathrm{Ca}(g)$ & $\mathrm{Mg}(g)$ & $\mathrm{Zn}(g)$ & $\mathrm{Fe}(g)$ & $\mathrm{Mn}(g)$ & $\mathrm{Cu}(g)$ \\
\hline $\mathrm{N}(s)$ & $\mathbf{0 . 9 9 8}$ & -0.058 & 0.851 & -0.713 & -0.844 & -0.363 & 0.203 & -0.671 & -0.881 \\
$\mathrm{P}(s)$ & 0.596 & 0.632 & 0.173 & -0.563 & -0.714 & -0.667 & -0.035 & -0.726 & -0.884 \\
$\mathrm{~K}(s)$ & -0.578 & 0.833 & -0.478 & 0.705 & 0.598 & 0.342 & 0.353 & 0.517 & 0.282 \\
$\mathrm{Ca}(s)$ & -0.472 & 0.398 & 0.030 & $\mathbf{0 . 9 3 9}$ & 0.817 & $\mathbf{0 . 9 1 8}$ & 0.795 & $\mathbf{0 . 9 0 7}$ & 0.515 \\
$\mathrm{Mg}(s)$ & -0.511 & 0.369 & -0.005 & $\mathbf{0 . 9 5 4}$ & 0.845 & $\mathbf{0 . 9 2 5}$ & 0.766 & $\mathbf{0 . 9 2 6}$ & 0.558 \\
$\mathrm{Zn}(s)$ & 0.094 & 0.713 & -0.376 & -0.320 & -0.388 & -0.672 & -0.300 & -0.532 & -0.514 \\
$\mathrm{Fe}(s)$ & 0.196 & 0.334 & -0.388 & -0.631 & -0.605 & $\mathbf{- 0 . 9 2 0}$ & -0.646 & -0.777 & -0.542 \\
$\mathrm{Mn}(s)$ & -0.657 & 0.254 & -0.151 & $\mathbf{0 . 9 9 1}$ & $\mathbf{0 . 9 3 4}$ & $\mathbf{0 . 9 2 5}$ & 0.633 & $\mathbf{0 . 9 7 9}$ & 0.712 \\
$\mathrm{Cu}(s)$ & -0.607 & 0.412 & $\mathbf{- 0 . 9 2 5}$ & 0.116 & 0.206 & -0.386 & -0.557 & -0.048 & 0.228 \\
\hline
\end{tabular}

Note: narked correlations are significant at $p<0.10 \mathrm{~N}=4 ;(g)$ : grass $(D$. antarctica $) ;(s)$ : soil

of leachates from nearby rookeries (P14, P15, P17) (Fig. 4e) or to nutrient concentration by melting water channels (P5, P11). These moss carpets afford high thermal insulation, leading to shallow, ice-cemented permafrost occurrence and a thin active layer of 40-50 cm deep (P14, P15 and P17).

\subsubsection{Moss turf and grass sub-formation}

The two higher plants $D$. antarctica and $C$. quitensis, which form cushions closely interspersed with moss Sanionia, are concentrated in more stable areas near large Larus dominicanus (Gull) nests (P17 and P18) and around penguin rookeries (Stranger Point, marine terraces P6, P11) (Fig. 4b).

These are the oldest exposed areas on Potter Peninsula, and most soils are well drained and quite developed. The sparseness of $D$. antarctica tufts within Polytrichales moss carpets indicates a more advanced stage of succession, as suggested by Schaefer, C. E. G. R. et al. (2004) and Francelino et al. (2011) for the same region. Regarding the ecological relationships of $D$. antarctica, Smykla et al. (2007) pointed out that, although it is widely distributed in maritime Antarctica landscapes, it shows a preference for old rookeries and their vicinities, gradually reducing its frequency away from these rich nutrient spots. Victoria et al. (2013) found that grasses and mosses in shallow soil de- veloped on the surface of basalt dyke, strongly influenced by L. dominicanus colonies. Overall, mixed plant communities are preferably associated with ornithogenic sites (Simas et al., 2008), and are probably dependent on high nutrient status, as observed in P13, P16 and P12.

\subsubsection{Fruticulose and foliose lichen sub-formation}

Macrolichen communities are widespread in extensive areas from sea level to high inland on dry stables or exposed soils (Longton, 1988). Lichens have a low biomass but were widely distributed across Potter Peninsula landscapes, where they formed dense stands on rocky cryoplanation surfaces, felsenmeer and stables slopes (Fig. 4c). They account for the initial stages of rock and soil weathering, and some organic matter arising from decomposing lichens was found in the subsurface, especially on the surface of large rock fragments. Soils under almost pure stands of Usnea sp. or mixed with $H$. lugubris and Umbilicaria sp. were observed on Potter Peninsula, probably forming the most extensive communities of all King George Island (P3, P1, P7 and P8). They covered more than $0.5 \mathrm{~km}^{2}$ of ice-free area. 

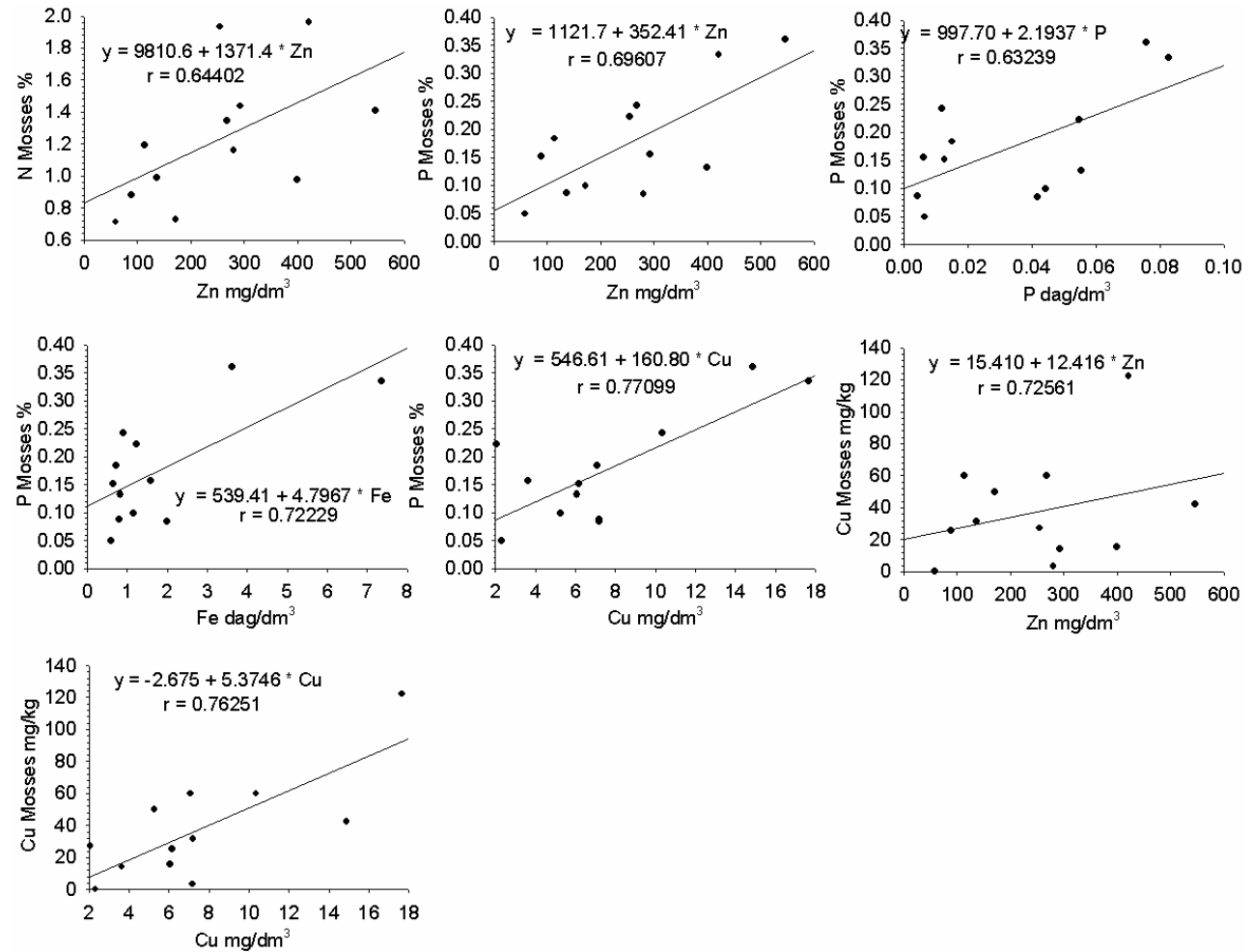

Figure 6. Graphs illustrating the correlation between soil macro- and micronutrients available and total plant amounts in mosses.

\subsubsection{Fruticulose lichens/short moss turf and cushion sub-formation}

These communities occurred on soils with some degree of ornithogenic influence from abandoned rookeries at Stranger Point, and on marine terraces and mostly at elevated areas with stable, well-drained soils (P4, P7, P8) (Fig. 4d). They represent the larger sub-formation mapped in the present work, characterized by mixed fruticulose lichens, short moss turf and small cushion sub-formation. They range from driest soils to rather moist habitats with acid substrata (Longton, 1988), and are associated basically with $D$. antarctica, mosses (Sanionia) and Prasiola. Furthermore, they also occur on rock outcrops, and coarse fragments on moraine, talus and protalus deposits (Victoria et al., 2013).

\subsubsection{Macroscopic alga sub-formation}

The green alga Prasiola is conspicuous in pebbly soils adjacent to Stranger Point penguin rookeries and bird nests (Fig. 4f) since it tolerates local trampling and occasional manuring, as well as low $\mathrm{pH}$ and high $\mathrm{N}$ availability (Longton, 1988). It also forms assemblages with ornithocoprofilous lichen Mastodia tesselata, a lichenized form of P. crispa, which occurs preferably on large rock surfaces found within the same area. The typical pedoenvironments are P12 and P16.

\subsubsection{Soil-plant and landscape relationships}

In maritime Antarctica, soils are formed predominantly from basaltic and andesitic volcanic rocks. There, although physical weathering dominates, chemical alteration of parent material also occurs, the mineral substrate being an important source of $\mathrm{K}$ and $\mathrm{Ca}$ (Simas et al., 2008). Waterlogged areas normally show higher contents of soluble nutrients due to their accumulation via melting water channels during summer. Ornithogenic influence results in high inputs of $\mathrm{N}$ and $\mathrm{P}$ mainly due to guano deposition, as described by Simas et al. (2008). Soils developed from volcanic rocks on Potter Peninsula showed variable values of bioavailable macroand micronutrients (Table 3 ).

As expected for a higher plant, D. antarctica showed the highest mean values for $\mathrm{Ca}, \mathrm{Zn}, \mathrm{Fe}$ and $\mathrm{Mn}$ (Table 4), whereas $\mathrm{P}, \mathrm{K}, \mathrm{Mg}$ and $\mathrm{Cu}$ were comparable to reference values from elsewhere in the same region (Simas, 2006; Schaefer, C. E. G. R. et al., 2004; Poblet et al., 1997). D. antarctica showed the highest values of all elements, possibly because it is closely associated with ornithogenic soils. The mean total values of $\mathrm{Ca}, \mathrm{Mg}, \mathrm{Fe}, \mathrm{Zn}$ and $\mathrm{Mn}$ were similar to those reported in previous works in maritime Antarctica (Table 5). However, the values of $\mathrm{P}, \mathrm{K}, \mathrm{Cu}$ obtained in the present study were higher than those reported in the literature (Simas, 2006; Schaefer, C. N. et al., 2004; Poblet et al., 1997; Allen et al., 1967; Tatur et al., 1997). In general, most 

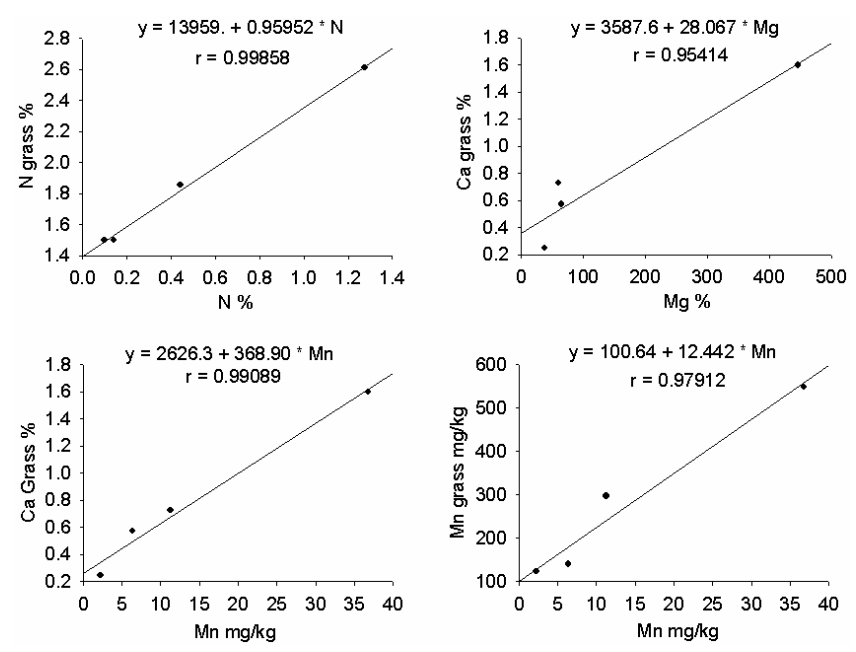

Figure 7. Correlation between soil macro- and micronutrients available and total plant amounts in $D$. antarctica.

elements had a wide range of values depending on the site characteristics and the age of plant communities.

Table 6 shows the correlation between soil available nutrients and total amounts in the dry matter. We observed a trend of increasing magnification of P in Mosses. Similarly, the same was observed for $\mathrm{Cu}$ in all plants and soils (Fig. 5). Due to its distribution associated with seasonal or permanent water accumulation, higher concentration of Fe was detected in the dry matter, with lower values of $\mathrm{K}, \mathrm{Mg}, \mathrm{Fe}, \mathrm{Mn}$ and $\mathrm{Cu}$ compared to places studied elsewhere in maritime Antarctica. Only $\mathrm{Ca}$ had greater values in mosses.

In lichens, little correlation with soil was observed since they develop on rock fragments that are not conditioned by soil underneath. However, the biomass can influence the deposition of elements in the soil. On the other hand, lichens can interfere in soil, but not vice versa.

Mosses showed little correlation between the available and the total plant concentration. Mosses increased $\mathrm{P}$ concentration correlated with improved availability of $\mathrm{P}, \mathrm{Zn}, \mathrm{Cu}$ and Fe in the soil.

Grasses showed a tight relationship with soil nutrient availability (Table 7). D. antarctica is best developed on nutrient-rich soils under a more advanced weathering stage. These plants have an apparent tolerance to high $\mathrm{Fe}$ availability, with high amounts of $\mathrm{Fe}$ in their biomass. The total amounts of $\mathrm{P}, \mathrm{Ca}, \mathrm{Mg}$ and $\mathrm{Mn}$ in the plant biomass of $D$. antarctica showed to be positively correlated with bioavailable levels in soils, although $\mathrm{Fe}$ and $\mathrm{Zn}$ showed an opposite trend (Fig. 6).

\section{Discussions}

The vegetation mapping shows widespread areas with vegetation cover in small patches, occupying different landscape positions and showing decreasing diversity and biomass from the coastal zone to inland areas, where sub-desert conditions prevail. In areas protected from winds and exposed to solar radiation, bryophytes, grasses and algae receive moisture and warmth and grow in close stands (Bargagli, 2005). D. antarctica is usually associated with abandoned bird nest sites with higher biodiversity. Lichens predominate in drier and windexposed habitats in inland (Bargagli, 2005; Francelino et al, 2011). Consistent with our observations, Kim et al. (2007) observed similar widespread development of such lichen communities on rocky surfaces distant from ornithogenic spots at the nearby Barton Peninsula. Eventually, lichens form associations with mosses at both sites. Lichens have a poor relationship to soil chemical, due to absorption of nutrients by directly contacting with their structures with air and water. Also, lichens are good bioindicators of air pollutants such as heavy metals (Bargagli et al., 1995; Poblet et al., 1997; Simas, 2006) because of their uptake of the elements dissolved in rain water or melting snow.

According to Schaefer, C. N. et al. (2004) bryophytes are adapted to environments with higher humidity, which can be either saline or eutrophic. The humic horizons, formed by the cycling of the biomass of mosses, serve as reservoirs of nutrients in organic colloids (Allen et al., 1967), which depend on the contribution of the elements via precipitation and snow melt channels. The concentrations of elements in moss samples often reflect the biogeochemical nature of soils and rocks rather than atmospheric input of elements (Bargagli, 2005). According to Allen et al. (1967), rainfall inputs are the dominant source of nutrient supply to moss carpets growing on deep peat. However, on Potter Peninsula the nutrient content of precipitation is not high and survival depends on the capacity of living mosses and organic matter in colloidal forms to retain nutrients. In this area, as elsewhere in Antarctica, climate and landscape-soil stability play a dominant role in controlling both the establishment of vegetation and soil development.

Our data suggest that higher concentrations of $\mathrm{Fe}, \mathrm{Zn}, \mathrm{N}$ and $\mathrm{P}$ in soils are inversely correlated with the concentrations of $\mathrm{K}, \mathrm{Ca}, \mathrm{Mg}, \mathrm{Zn}, \mathrm{Fe}, \mathrm{Mn}$ and $\mathrm{Cu}$ in grasses. On the other hand, high bioavailable concentrations of $\mathrm{Ca}, \mathrm{Mg}, \mathrm{Mn}$ and $\mathrm{K}$ in soils contribute to a high uptake of microelements by $D$. antarctica. These data confirm a previous work at Stranger Point by Tatur et al. (1997), in which the chemical composition of $D$. antarctica growing in the marginal zones of active rookeries showed the highest concentrations of N, P, $\mathrm{Ca}, \mathrm{Zn}$ and $\mathrm{Cu}$ derived from decomposing guano. Higher $\mathrm{P}$ levels from guano appear to be an important determinant of vegetation patterns (Michel et al., 2006). Bioaccumulation of metals in mosses and $D$. antarctica is greatly determined by substrate geochemistry (Simas, 2006). 


\section{Conclusions}

The distribution of plant communities in ice-free areas in Potter Peninsula has a close relationship with geomorphological and pedological attributes, which also influence the chemical composition of plants. The main points are as follows:

1. Plant communities on Potter Peninsula cover $23 \%$ of the ice-free area, occupying different landscape positions and showing decreasing diversity and biomass from the coastal zone to inland areas, where sub-desert conditions prevail.

2. There is a clear dependency between landform and soils with vegetation. Soils with greater moisture or poorly drained and acid to neutral $\mathrm{pH}$ are favourable for moss sub-formations. Saline, organic-matter-rich ornithogenic soils of former penguin rookeries have greater biomass and diversity, with associations of mosses and grasses, while stable felsenmeers and flat rocky cryoplanation surfaces are the preferred sites for Usnea and H. lugubris lichens, at the highest level.

3. Lichen sub-formations cover the largest vegetated area, showing varying associations with mosses.

This survey will allow for accurate monitoring of plant communities in ice-free areas from Potter Peninsula. It may be possible to verify, with further map surveys, the dynamics of vegetation cover in ice-free areas.

Edited by: M. Oliva

\section{References}

Allen, S. E,. Grimshaw, H. M., and Holdgate, M. W.: Factors Affecting the Availability of Plant Nutrients on an Antarctic Island, J. Ecol., 55, 381-396, 1967.

Bargagli, R.: Environmental Contamination, Climate Change, and Human Impact, Ecological Studies, 175, 395 pp., doi:10.1007/b137608, 2005.

Bargagli, R., Brown, D. H., and Nelli, L,: Metal biomonitoring with mosses: Procedures for correcting for soil contamination, Environ. Pollut., 89, 169-175, 1995.

Birkenmajer, K.: Geology of Volcanic Rocks (Upper CretaceousLower Tertiary) at Potter Peninsula, King George Island (South Shetland Islands, West Antarctica, Bulletin of the Polish Academy of Sciences, Earth Sciences, 46, 147-155, 1998.

Braga, J. M., and Deffelipo, B. V.: Determinação espectrofotométrica de fósforo em extratos de solo e plantas, R. Ceres, 21, 73-85, 1974.

Congalton, R. G. and Green, K., Assessing the accuracy of remotely sensed data: Principles and practices, New York, Lewis Publishers, 137, 210 pp., 1999.

Embrapa: Manual de métodos de análise de solo, 2, EMBRAPA/CNPS, Rio de Janeiro, 212 pp., 1997.
Ferron, F. A., Simões, J. C., Aquino, F. E., and Setzer, A. W.: Air temperature time series for King George Island, Antarctica, Pesquisa Antártica Brasileira, 4, 155-169, 2004.

Francelino, M. R., Schaefer, C. E. G. R., Simas, F. N. B., Fernandes Filho, E. J., Souza, J. J. L. L., and Costa, L. M.: Geomorphology and soils distribution under paraglacial conditions in an ice-free area of Admiralty Bay, King George Island, Antarctica, Catena, 85, 194-204, 2011.

Fretwell, P. T., Hodgson, D. A., Watcham, E. P., Bentley, M. J., and Roberts, S. J.: Holocene isostatic uplift of the South Shetland Islands, Antarctic Peninsula, modelled from raised beaches, Quaternary Sci. Rev., 29, 1880-1893, 2010.

Fretwell, P. T., Convey, P., Fleming A. H., Peat, H. J., and Hughes K. A.: Detecting and mapping vegetation distribution on the Antarctic Peninsula from remote sensing data, Polar Biol., 34, 273-281, 2011.

Longton, R. E.: The briology of polar bryophytes and lichens, Cambridge University Press, Cambridge, 391 pp., 1988.

Lusky, J. C., Vallverdú, R. A., Gómez Izquierdo, D. R., del Valle, R. A., and Felske, H.: Mapa digital del peninsula Potter isla 25 de Mayo (King George Island), Instituto Antártico Argentino, 10 pp., 2001.

Kim, J. H, Ahn, Y., Lee, K. S., Chung, H., and Choi, H.: Vegetation of Barton Peninsula in the neighbourhood of King Sejong Station (King George Island, maritime Antarctic), Polar Biol., 30, 903 916, 2007.

Kraus, S. and del Valle, R.: Geological map of Potter Peninsula (King George Island, South Shetland Islands, Antarctic Peninsula), Instituto Antártico Chileno, Punta Arenas, Chile and Instituto Antártico Argentino, Buenos Aires, Argentina, doi:10.1594/PANGAEA.667386, 2008.

Michel, R. F. M, Schaefer, C. E. G. R., Dias, L., Simas, F. N. B., Benites, V., and Mendonça, E. S.: Ornithogenic Gelisols (Cryosols) from Maritime Antarctica: pedogenesis, vegetation and carbon studies, Soil Sci. Soc. Am. J., 70, 1370-1376, 2006.

Myrcha, A. and Tatur, A.: Ecological role of current and abandoned penguin rookeries in the land environment of the Maritime Antarctic, Pol. Polar Res., 12, 3-24, 1991.

Øvstedal, D. O and Smith, R. I. L.: Lichens of Antarctica and South Georgia: guide to their identification and ecology, Cambridge University Press, Cambridge, 424 pp., 2001.

Poblet, A., Andrade, S., Scagliola, M., Vodopivez, C., Curtosi, A., Pucci, A., and Marcovecchio, J.: The use of epilithic Antarctic lichens (Usnea aurantiacoatra and $U$ antartica) to determine deposition patterns of heavy metals in the Shetland Islands, Antarctica, Sci. Total Environ., 207, 187-194, 1997.

Poelking, E. L.: Criossolos e monitoramento climático da península Potter, Antártica Marítima, Soil Science Department, Federal University of Viçosa, Viçosa, Minas Gerais, Brazil, 119 pp., 2011.

Schaefer, C. E. G. R., Pereira, A. B., Francelino, M. R., Fernandes Filho, E. I., Simas, F. N. B., Costa, L., and Oliveira, A. C.: Comunidades vegetais na Península Keller: Ecologia e Padrões de Distribuição, edited by: Schaefer, C. E. R, Francelino, M. R, Simas, F. N. B, and de Albuquerque Filho, M. R, in: Ecossistemas costeiros e monitoramento ambiental da Antártica marítima: Baía do Almirantado, IIha Rei George, Viçosa, NEPUT, 47-58, 2004. 
Schaefer, C. N., Francelino, M. R., Albuquerque Filho, M. R., Simas, F. N. B., Costa L., Pereira V., Guerra M., and Gomes, M.: Indicadores biogeoquímicos de metais pesados e elementos maiores em solos e coberturas vegetais na península Keller, Antartica, edited by: Schaefer, C. E. R, Francelino, M. R, Simas, F. N. B, and de Albuquerque Filho, M. R, in: Ecossistemas costeiros e monitoramento ambiental da Antártica marítima: Baía do Almirantado, IIha Rei George, Viçosa: NEPUT, 47-58, 2004.

Simas, F. N. B.: Solos da Baía do Almirantado, Antártica marítima, PhD Thesis (Soil Science and Plant Nutrition), Soil Science Department, Federal University of Viçosa, Viçosa, Minas Gerais, Brazil, 149 pp., 2006.

Simas, F. N. B., Schaefer, C. E. G. R., Melo, V. F., AlbuquerqueFilho, M. R., Michel, R. F. M., Pereira, V. V, Gomes, M. R. R., and Costa, L. M.: Ornithogenic cryosols from Maritime Antarctica: phosphatization as a soil forming process, Geoderma, 138, 191-203, 2007.

Simas, F. N. B., Schaefer, C. E. G. R., Albuquerque Filho, M. R., Francelino, M. R., Fernandes Filho, E. I., and Costa, L. M.: Genesis, properties and classification of Cryosols from Admiralty Bay, Maritime Antarctica, Geoderma, 144, 116-122, 2008.
Smith, R. I. and Gimingham, C. H.: Classification of cryptogamic communities in the Maritime Antarctic, Br Antarct Surv Bull, 43, 25-47, 1976.

Smykla, J., Wolek, J., and Barcikowski, A.: Zonation of Vegetation Related to Penguin Rookeries on King George Island, Maritime Antarctic, Arctic Antarctic and Alpine Research, 39, 143-151, 2007.

Tatur, A. and Myrcha, A.: Soils and Vegetation in Abandoned Penguin Roockeries (Maritme Antarctic) NIPR, Symp, Polar Biol., 2, 181-189, 1989.

Tatur, A., Myrcha, A., and Niegodziz, J.: Formation of abandoned penguin roockery ecosystems in the Maritime Antarctic, Polar Biol., 17, 405-417, 1997.

Tedesco, J. M., Gianello, C., Bissani, C. A., Bohnem, H., Volkweiss, S. J.: Análise de solo, plantas e outros materiais, Porto Alegre: Departamento de solos, Faculdade de Agronomia. Universidade Federal do Rio Grande do Sul, 2, 174 pp., (Boletim Técnico, 5), 1995.

Victoria, F. C., de Albuquerque, M. P., Pereira, A. B., Simas, F. N. B., Spielmann, A. A., Schaefer, and Carlos E. G. R.: Characterization and mapping of plant communities at Hennequin Point, King George Island, Antarctica, Polar Res., 32, 1-11, 2013.

WRB: World Reference Base for Soil Resources, 2006, first update 2007, World Soil Resources Reports No. 103, FAO, Rome, 216 pp., 2006. 